\title{
Gioconda Mussolini: uma travessia bibliográfica
}

\author{
Andrea Ciacchi \\ Professor do Departamento de Ciências Sociais - \\ Universidade Federal da Paraíba
}

\begin{abstract}
RESUMO: Com este trabalho, dou continuidade à divulgação dos resultados de uma pesquisa voltada para a reconstrução da trajetória intelectual da professora Gioconda Mussolini, pioneira no ensino de antropologia na Faculdade de Filosofia da USP, entre 1944 e 1969. Nesta etapa, resenho a sua produção mais significativa: seis artigos e a co-autoria de um livro, textos dedicados a vários aspectos da vida cultural e social de populaçōes de pescadores do litoral do estado de São Paulo, produzidos entre 1944 e 1961 e fruto de intensas e numerosas pesquisas de campo. O objetivo da análise é mostrar como o conjunto das atitudes metodológicas que se revelam na formulação dos textos remete para uma superação crítica dos "estudos de comunidade", no contexto dos quais Gioconda havia se formado, tanto como aluna da USP e da Escola Livre de Sociologia e Política quanto como colega e colaboradora de representantes dessa vertente (Donald Pierson, Emilio Willems e Egon Schaden, entre outros); e que, nesse sentido, ela se aproxima mais das perspectivas de outros colegas seus, como Antonio Candido e Florestan Fernandes. Finalmente, aponto os primeiros elementos que permitem ligar a sua produção aos rumos sucessivos do campo da etno-antropologia da pesca no Brasil.
\end{abstract}

PALAVRAS-CHAVE: Gioconda Mussolini, antropologia e sociologia no Brasil, antropologia da pesca. 
A relevância de Gioconda Mussolini para a antropologia brasileira desdobra-se em três direções. Primeiro, por ela ter protagonizado os primórdios do ensino da disciplina, numa instituição pioneira como a Faculdade de Filosofia, Ciências e Letras (FFCL) da Universidade de São Paulo, a partir de $1938,{ }^{1}$ concorrendo para a formação de muitos cientistas sociais; segundo, por sua contribuição ao campo da "antropologia da doença”, por meio de sua dissertação de mestrado; finalmente, e sobretudo, o nome dela é referência fundamental para os estudos brasileiros sobre pesca, cultura e organização social de comunidades litorâneas, em geral, e populações caiçaras do litoral de São Paulo, em particular. O subcampo disciplinar da antropologia da pesca tem no nome de Gioconda Mussolini uma espécie de "mãe fundadora". Suas pesquisas de campo ainda orientam os estudos de muitos pesquisadores contemporâneos. Na primeira e na terceira dessas três direções, não é mais nem tanto o "pioneirismo" a ser marca de reconhecença, mas as verdadeiras novidades teóricas, metodológicas e epistemológicas que ela tentou introduzir em sua produção acadêmica, a despeito de sua reduzida dimensão e da dispersão a que ela foi submetida. Assim, uma primeira hipótese deste trabalho é que essas novidades determinaram tanto o clima (ora negativo ora indiferente) com que seus trabalhos foram recebidos no lugar específico em que eram situados (a Cadeira de Antropologia da USP, onde ela lecionou de 1944 a 1969) quanto a sua própria escassez, pois a seu conjunto falta justamente a peça que lhe arremataria o sentido: a inconclusa e desaparecida tese de doutorado. Mesmo assim, o conjunto de artigos e outros textos de Gioconda Mussolini parece mais que suficiente para que a sua figura reassuma a posição central que, como professora de sala de aula, ninguém conseguiu negar-lhe. Essa tese de doutoramento, aliás, figurará aqui como a pedra de toque, ainda que ausente, para os demais trabalhos que ela conseguiu concluir e publicar. Estes, por sua vez, iluminam o vazio que seria ocupado pela tese, numa 
Revista de Antropologia, São Paulo, USP, 2007, v. 50 No 1.

tentativa de imaginar uma solidez coerente, representada por sua contribuição às ciências sociais do país.

Entretanto, as "histórias da antropologia brasileira" mal lembram dela. Nas palavras de alguns dos protagonistas dessa história, em oportunidades não oficiais ou academicamente menos relevantes (entrevistas, depoimentos, testemunhos pessoais), o nome de Gioconda aparece com destaque e, até, com afeto e reconhecimento pessoal e intelectual. Mas sem que se proceda a uma apreciação de sua obra publicada nem que se contextualize a sua atuação no panorama dos primórdios do ensino institucional da antropologia em São Paulo e no Brasil. ${ }^{2}$

Definir a posição de Gioconda Mussolini no campo brasileiro da antropologia e no subcampo da antropologia da pesca é, portanto, o objetivo deste estudo. ${ }^{3}$ Essa definição parece-me depender da observação de duas esferas - distintas e articuladas - da atuação de Gioconda: a professora de antropologia da Faculdade de Filosofia, Ciências e Letras da Universidade de São Paulo, de 1944 a 1969; e a autora de alguns textos seminais e inaugurais para aquilo que se tentará definir como campo brasileiro da "antropologia da pesca". Como pano de fundo de tudo, aqui (a justificativa para esta pesquisa, a "participação" que provavelmente nem sempre estará disfarçada no meu observar e ouvir, a insistência e até mesmo a repetição de alguns pormenores biográficos, a busca talvez obsessiva por todos os atalhos e ligações possíveis para a rede de contatos pessoais e institucionais de Gioconda, e muito mais), está o sentimento de que já não podia mais demorar a ser revisitada a trajetória biográfica e intelectual daquela que foi a primeira mulher brasileira a fazer do ensino da antropologia social e cultural o seu destino profissional. ${ }^{4} \mathrm{Um}$ destino que, algo teatralmente, verá a sua morte em cena, poucos minutos depois de ter ministrado a sua última aula, nos barracôes do novo e ainda precário campus da USP, em 28 de maio de 1969. 
O curriculum vitae redigido por Gioconda Mussolini em 1965, por ocasião de um processo de ascensão funcional na Faculdade de Filosofia, Ciências e Letras da Universidade de São Paulo, é o documento mais seguro para acompanhar a sua trajetória bibliográfica. Aqui, concentrome em sua produção diretamente ligada aos aspectos da cultura e da organização social dos pescadores e das populações caiçaras do litoral norte de São Paulo, e a alguns textos que, mais indiretamente, se referem à mesma região, embora não abordem expressamente ou exclusivamente o trabalho da pesca. Além disso, construo a hipótese de que as temáticas, os conteúdos teóricos e as diretrizes metodológicas dessa produção estão vinculados à sua trajetória intelectual e, especificamente, aos ambientes acadêmicos e extra-acadêmicos por ela freqüentados e, como veremos, aos embates institucionais travados na FFCL da USP.

Uma parcela significativa da produção bibliográfica de Gioconda, por exemplo, é constituída por textos sobre folclore e cultura popular: os dois artigos, "Festa de folia" e "Festa de devoção", publicados na Folha da Manhã em 1946 - um estudo sobre a função integrativa das festas folclóricas no litoral paulista -, o ensaio "Os pasquins no litoral norte de São Paulo e suas peculiaridades na Ilha de São Sebastião” - trabalho apresentado em 1949 ao III Concurso de Monografias Folclóricas, instituído pelo Departamento de Cultura de São Paulo e contemplado com o $1^{\circ}$ Prêmio -, publicado na Revista do Arquivo Municipal (cxxxiv, 1950), e, finalmente, a comunicação "Persistência e mudança em sociedades de 'folk' no Brasil", apresentada no Xxxi Congresso Internacional de Americanistas e publicada em seus Anais em 1955. É necessário adiantar, aqui, que a influência da Sociedade de Etnografia e Folclore, de cujos quadros e atividades ela participou entre 1936 e 1938, sobre a personalidade intelectual de Gioconda Mussolini ultrapassa o mero plano das escolhas temáticas. De fato, tal influência desdobra-se no chão mais sutil e sólido do estilo da autora, aqui compreendido como o conjunto do 
Revista de Antropologia, São Paulo, USP, 2007, v. 50 No 1.

registro de sua escrita, dos cuidados metodológicos e da abrangência teórica do tratamento dispensado a fontes, informantes e registros - o que, aliás, se estende a seus artigos mais diretamente dedicados ao tema da pesca artesanal.

Por outro lado, os anos passados como aluna de mestrado em Ciências Sociais na Escola Livre de Sociologia e Política (ELSP) de São Paulo (1940-1945) também são decisivos. O envolvimento nas atividades da seção de estudos pós-graduados da ELSP nesses anos, sob a batuta de Donald Pierson, implicava, como se sabe, a participação em pequenas expediçõos de treinamento etnográfico. Entretanto, é ainda sob a orientação de Roger Bastide, na Cadeira de Sociologia I, na Faculdade de Filosofia da USP, que Gioconda participa de uma visita realizada em maio de 1943, na cidade paulista de Tietê, para coleta de "material folclórico". A turma fora "a convite da Prefeitura local assistir a um batuque” (Candido, 1947, p. 97) e era composta de Bastide, Lavínia Costa, Gilda de Mello e Souza, José Francisco de Camargo, Gioconda Mussolini e Antonio Candido, o qual se demora mais uns dias após o encerramento da festa e redigirá um artigo publicado na revista Sociologia em 1947 (ibid.).

Os anos imediatamente sucessivos à defesa do mestrado (1945) marcam também o começo da carreira docente da professora Mussolini. São os anos mais bem documentados, seja porque dispomos da documentação oficial - bem ou mal - expedida e conservada pela Faculdade de Filosofia, seja porque o número de testemunhas aumenta consideravelmente ao diminuir a distância temporal que nos separa dessa época. Nesse período, Gioconda participa de pesquisas de campo coordenadas por colegas e ex-professores, desenvolve intensa atividade de sala de aula, orienta alunos do mestrado em Antropologia e do curso de graduação em Ciências Sociais da USP, publica resenhas de obras antropológicas, nacionais e estrangeiras, realiza as próprias pesquisas de campo no lito- 
ral de São Paulo, participa de congressos e simpósios, profere numerosas conferências e palestras no Brasil e no exterior, publica artigos em revistas científicas, colabora na feitura e no dia-a-dia do editorial da $R e-$ vista de Antropologia, fundada por Egon Schaden em 1953, traduz livros e artigos e organiza uma coletânea de ensaios de antropologia física, por estímulo de Florestan Fernandes, participa das primeiras reuniōes da recém-criada (1955) Associação Brasileira de Antropologia, da qual foi sócia-fundadora, pertence também à Associação dos Geógrafos Brasileiros e à Sociedade de Psicologia de São Paulo, substitui Schaden na direção da Cadeira por ocasião das viagens dele cada vez mais freqüentes, sobretudo à Alemanha nos anos 1960, e se dedica à sua tese de doutoramento. Tudo, menos esta última atividade, está relativamente bem documentado. Trata-se, como se vê, de um conjunto de tarefas e ações que, embora iniciado numa época institucionalmente distante da nossa, possui muitas semelhanças com aquilo que, hoje, constitui o repertório de responsabilidades do docente de uma universidade pública de primeira linha. Nesse contexto, realiza-se a maior parte de sua produção bibliográfica.

Além disso, Gioconda mantém-se próxima de alguns de seus ex-professores. É o caso, notadamente, de Emilio Willems, que desde 1941 era o catedrático da nova Cadeira de Antropologia (para a qual Gioconda se transferiria em 1945), com quem compartilhará duas importantes pesquisas de campo. A primeira, realizada na "vila" de Cunha (SP), em 1945 e 1946, ${ }^{5}$ resultará na publicação, em 1948, de Cunha: tradição e transição em uma cultura rural do Brasil. A mesma monografia será reeditada em 1961, com o título Uma vila brasileira: tradição e transição, omitindo-se assim o nome da cidade, que passa a ser chamada, nesta segunda edição, de Itaipava. ${ }^{6}$ Somente em 1987, com a publicação do depoimento de Willems por parte de Mariza Corrêa (1987, p. 120), tem-se acesso à informação de que o trabalho de campo foi realizado 
"em companhia de Gioconda Mussolini, Francisca Klovrza, Florestan Fernandes, Alceu Maynard de Araújo, Carlos Borges Schimidt e Paulo Florençano, colaboradores dedicados e inteligentes, alguns dos quais, anos depois, viriam a ocupar posições de grande distinção nas Ciências Sociais do Brasil". Pouco depois da publicação da primeira edição do livro de Willems, Gioconda Mussolini publicará na Revista do Museu Paulista, em 1949, uma resenha crítica do volume, em que, aliás, inicia o caminho de distanciamento dos aspectos mais problemáticos dos "estudos de comunidade". Entretanto, ainda em companhia de Willems, Gioconda Mussolini participará, em 1947, da pesquisa na ilha de Búzios, que resultará no livro publicado por Emilio Willems (“in cooperation with Gioconda Mussolini"), Buzios Island; a Caicara Community in Southern Brazil (Monographs of the American Ethnological Society, XX, New York), que só será publicado em português em 2003. No depoimento de 1987, Willems declara ter-se tratado de uma "investigação [...] extremamente penosa" (Corrêa, 1987, p. 121), sem revelar, contudo, os motivos dessas dificuldades. Além disso, menciona também os nomes de Oscar Rezende de Lima e Íris Koehler," "ambos estudantes da Escola Livre de Sociologia e Política, que subvencionou a expedição" (ibid.), como colaboradores de campo. Já no "Prefácio" à edição americana de 1952, o antropólogo alemão informa que

[...] o profundo conhecimento da Professora Mussolini sobre a cultura caiçara foi especialmente valioso para se obter um quadro claro da comunidade local. Cada membro do grupo focalizou sua atenção em um aspecto particular da cultura local. Reuniōes diárias e trocas de experiências e sugestôes foram extremamente compensadoras. (Willems, 2003, p. 14)

Ora, embora não haja mais nenhum detalhe sobre a divisão de tarefas e de focos entre os quatro pesquisadores, nem sobre a organização 
logística e mesmo hierárquica entre eles, é claro que a informação que se retém, aqui, é a relativa ao "profundo conhecimento" de Gioconda sobre a cultura caiçara. Entretanto, a frase, longe de levar a conclusões certas, constitui mais uma questão a ser resolvida: como complementála com evidências que documentem os passos que levaram a assistente de Willems a adquirir essa experiência? Pois o problema é que, até esse mês de julho de 1947, Gioconda apenas publicara dois artigos, sobre "o cerco da tainha" e "o cerco flutuante" (1945 e 1946, respectivamente), mas sobre as suas pesquisas na ilha de São Sebastião (motivação inicial, período, duração, equipe, condições etc.), de onde resultaram os dois artigos, nada sabemos. Trata-se, na realidade, de uma dúvida que, no estado atual da pesquisa, dificilmente será resolvida. Mas em volta dela gira uma possibilidade de esclarecimento do que se mantém como o problema principal desta investigação: a reconstrução da atividade antropológica de Gioconda Mussolini sobre o tema da pesca artesanal.

A sua produção bibliográfica menor é constituída por uma série de materiais heterogêneos: dois artigos de jornal (1946), o texto de um livro ilustrado sobre Povos e trajes da América Latina (em colaboração com Egon Schaden, com gravuras de Belmonte, 1947), cinco verbetes para um dicionário de sociologia publicado na Alemanha (1959), a organização de um volume de ensaios de antropologia física (1969), muitos dos quais traduzidos por ela, a tradução de um livro de paleontologia e de um de antropologia física, e 13 resenhas bibliográficas.

Mas o que vai nos interessar, a partir de agora, são seus artigos sobre pesca e pescadores.

Em Sociologia: revista didática e científica, fundada em 1939 por Emilio Willems (cf. Jackson, 2004), aparece em 1945 o artigo "O cerco da tainha na Ilha de São Sebastiāo", o primeiro publicado por Gioconda sobre temas relativos à pesca. Logo a seguir, em 1946, aparece na mes- 
Revista de Antropologia, São Paulo, USP, 2007, v. 50 No 1.

ma revista "O cerco flutuante: uma rede de pesca japonesa que teve a Ilha de São Sebastião como centro de difusão no Brasil”. Os dois artigos, embora nem um nem o outro o declarem, estão evidentemente ligados e articulados entre si de forma que o segundo se configura como continuação e complementação do primeiro. Não só o campo empírico é o mesmo (a ilha de São Sebastião, seus espaços marítimos e as localidades vizinhas, com freqüentes deslocamentos por todo o litoral do estado de São Paulo), mas, principalmente, por se tratar de textos que compartilham um mesmo âmbito temático, só aparentemente atrelado a técnicas de confecção e utilização de armadilhas de pesca e a técnicas de pesca em geral.

De fato, o foco, inicialmente concentrado nos aspectos materiais e tecnológicos da captura de alguns peixes, alarga-se imediatamente para um conjunto de questôes que, como veremos, constituirão o grande tema das preocupações intelectuais de Gioconda Mussolini até a sua morte, em 1969, e que se prendem à circulação de populações, de trabalhadores e de elementos de natureza cultural e social influenciados por essas questões migratórias e demográficas. Nesses dois artigos, provavelmente redigidos no mesmo período em que ela concluía a redação de sua dissertação de mestrado sobre populações indígenas, não há nenhuma reflexão teórica ou metodológica mais aprofundada, o que nos permitirá, aliás, considerar o lugar dessa reflexão na produção de Gioconda, que, pelo contrário, atribuía imensa relevância a tais fundamentaçôes. Ela encontra-se, sobretudo, na comunicação apresentada ao XXXI Congresso de Americanistas (São Paulo, 1954) e publicada nos Anais do evento, em 1955 - que abordo mais adiante neste trabalho.

Mas voltemos aos dois artigos inaugurais para mostrar como eles parecem anunciar o recorte teórico de Gioconda sem, entretanto, esmiuçálo. Neles, porém, aparecem elementos instigantes quando consideramos que nada ainda sabemos sobre datas, períodos e duração de suas visitas 
aos campos. Deve ter se tratado de algo não episódico, se a autora reporta, com segurança, um conjunto de discursos êmicos nos quais parece sentir-se muito à vontade. Narrativas nativas e expressões locais, conhecimentos tradicionais e elementos trazidos mais recentemente são o recheio empírico mais relevante desses dois artigos. Ela, de fato, declara logo que teve "oportunidade de conversar com inúmeros mestres de lanchas" (Mussolini, 1980, pp. 261-2), ${ }^{8}$ e a maioria das informações etnográficas apresentadas parecem mesmo ter como fonte os pescadores da ilha de São Sebastião e a própria observação participante da autora. $\mathrm{O}$ artigo traz descrições importantes, além de inéditas para a época: constituição das tripulações dos barcos que se dedicam à pesca da tainha, tanto as lanchas que empregam assalariados quanto as canoas dos "pequenos pescadores"; rotas de comercialização do pescado; equipamentos de captura, suas técnicas de fabricação, reparo e utilização, e seus custos; conhecimentos ecológicos dos mestres; ideologia dos pescadores; partilha das receitas. Mas o pano de fundo do artigo é a distinção entre essa "pequena" pesca à tainha e a praticada pelos barcos e pelas traineiras das companhias de Santos, distinção que a autora desdobra, por enquanto, em termos econômicos, técnicos e ideológicos.

O recorte etnográfico desse artigo, portanto, configura um périplo que inclui a ilha de São Sebastião, cercada e percorrida, por sua vez em toda a sua extensão (praia do Bonete, baía dos Castelhanos, Saco do Sombrio), o canal e os "baixos" de São Sebastiāo, já no continente, e daqui até Santos e Ilha Grande. O período em que Gioconda esteve nessa região, como dissemos, deve ter correspondido ao recesso de inverno do ano letivo, estação correspondente, justamente, à época da tainha no litoral brasileiro. E, provavelmente, não foi curto, se, depois de descrever o sistema pelo qual um vigia "anuncia um cardume em movimento [por meio do] toque repetido da buzina de rede, convidando os pescadores a tomar parte de um arrastão" (id., p. 267), a autora 
Revista de Antropologia, São Paulo, USP, 2007, v. 50 No 1.

acrescenta: "Quantas e quantas vezes ouvi o toque clamoroso, insistente, por horas a fio!" (ibid.).

Mas o foco principal do trabalho é constituído pela descrição pormenorizada da técnica do "cerco", que ocupa as últimas cinco páginas do texto. Trata-se, em absoluto, da primeira descrição dessa técnica, no Brasil, além de permitir efetivamente que o leitor visualize com precisão os movimentos das canoas, os lanços das redes de tresmalho, as batidas dos remos para assustar os peixes, o recolher das redes e até a partilha do pescado. Não posso afirmar com certeza se Gioconda embarcou numa canoa para acompanhar mais de perto esses cercos que ela nos restitui tão vigorosamente, mas uma conclusão de parágrafo deixa aberta essa possibilidade:

Muitas vezes uma canoa penetra dentro do círculo, a fazer barulho sobre os bordos com os remos para "assustar o peixe". A vibração dos remos na canoa produz um barulho surdo, característico, que fica nos ouvidos da gente, mesmo depois que acaba a estação. (id., p. 271)

Cinco anos mais tarde, os geógrafos Lysia e Nilo Bernardes, ao publicarem, na Revista Brasileira de Geografia, o artigo "A pesca no litoral do Rio de Janeiro", resultado de pesquisa de campo efetuada em 1949 sobretudo em Arraial do Cabo, Ilha Grande, Saquarema, Cabo Frio, com objetivos semelhantes aos de Gioconda Mussolini, limitam-se a uma descrição mais do que concisa:

O cerco da tainha é realizado por duas canoas, usando-se uma rede ou duas emendas, conforme a distância da terra e a quantidade do peixe a cercar. Partem as canoas do mesmo ponto e lançam a rede em semicírculo, puxando-a depois para a terra por meio de dois cabos. Em cada canoa seguem quatro homens, dois proeiros que remam e dirigem a operação e 
dois que soltam a rede, o chumbereiro $[$ sic $]$ e o popeiro, encarregados, respectivamente, da tralha, do chumbo e da cortiça. Esse tipo de cerco também é usado para cavala, bonito, enchova. (Bernardes \& Bernardes, 1950, p. 27)

É verdade, porém, que a visualização dessa técnica tão complexa é facilitada com o subsídio de alguns excelentes desenhos do próprio Nilo Bernardes. Na comparação mais ampla entre os dois trabalhos, porém, é evidente que, apesar de o artigo dos dois geógrafos fluminenses anunciar uma explanação do "gênero de vida dos pescadores", ele também se restringe aos processos de pesca empregados no litoral do Rio de Janeiro, onde os autores, concluindo, encontram, sobretudo, a "persistência dos aspectos tradicionais que ainda hoje tão bem caracterizam a pesca em todo esse litoral" (id., p. 37). Essa observação, portanto, coloca as duas perspectivas analíticas em posições reciprocamente opostas, o que se evidencia mais ainda no artigo sucessivo de Gioconda Mussolini, dedicado prioritariamente ao "cerco flutuante", aparelho de captura introduzido na ilha de São Sebastião por imigrantes japoneses, no qual o tema da mudança sociocultural é ainda mais evidente.

Uma boa parte do texto é dedicada à descrição das técnicas de construção dessa armadilha, a seus custos e a seu funcionamento (aspectos por meio dos quais Gioconda apresenta uma etnografia segura e já amadurecida). Mas o foco da autora está mais dirigido para as questôes que remetem à aceitação, por parte da população pesqueira local, de uma "novidade técnica" que acarreta, evidentemente, uma produção ideológica e narrativa que acompanha o percurso da própria rede. E esse aspecto não se limita a ser investigado na ilha, mas o leitor é levado a mapear a difusão e o uso do cerco flutuante em outras localidades do litoral pau- 
lista e, mais uma vez, a considerar as relações entre essa introdução e as atividades de pesca industrial praticadas desde o porto de Santos. Finalmente, e mais uma vez, os deslocamentos populacionais e as alterações demográficas ocorridas ao longo dos anos são outros tantos elementos que consentem um firme assentamento historiográfico nas argumentações e descrições da autora. Nesse sentido, o artigo configura-se, mais claramente do que o primeiro, como um "estudo de difusão cultural" (Mussolini, 1980, p. 280), por meio do qual foi possível concluir que

os padrões de intercâmbio e especialização que presidem à pesca inserem a Ilha num mundo muito mais amplo, comercializado, tornando-a, por isso mesmo, mais receptiva nesse setor de atividades. A ligação com Santos torna o pescador "familiar" com grande variedade de sistemas de pesca. Além disso, é pela pesca que o morador local sai da "economia de subsistência", incorporando-se a um sistema de exploração pecuniária à qual não é indiferente um meio mais adequado de obter maior lucro. (id., pp. 282-3)

A originalidade e o pioneirismo desses dois estudos revelam-se, entre outros aspectos, pela modestíssima presença de remissōes bibliográficas: no primeiro artigo, apenas a tese inédita de Maria Conceição Vicente de Carvalho, Santos e a geografia humana do litoral paulista, (aliás, a primeira tese em geografia no Brasil, orientada pelo também professor de Gioconda na FFCL, Pierre Monbeig), e, no segundo, apenas o Anuário da pesca marítima no estado de São Paulo (1945). Em outras palavras, trata-se de pesquisas inéditas, sobre temas novos, e cujas fontes foram quase exclusivamente etnográficas.

A ilha de São Sebastião volta a aparecer numa publicação de Gioconda Mussolini em 1950, com o já mencionado estudo sobre "Os pasquins do litoral norte do estado de São Paulo e suas peculiaridades na Ilha de São Sebastião". A pesquisa que o informa e documenta ${ }^{9}$ come- 
çou na localidade de Bonete, em janeiro de 1947, como declarado pela autora (Mussolini, 1950, p. 11), a qual acrescenta que "um simples acaso foi a força propulsora que me impeliu às análises aqui apresentadas" (ibid.). Sabemos, porém, que Gioconda Mussolini andava pela ilha pelo menos desde 1945. O artigo, como já foi dito, está situado no contexto das atividades da Sociedade de Etnografia e Folclore, criada por incentivo de Mário de Andrade em 1936. Nesse sentido, as suas questóes principais são:

[...] o processo de transformação por que passou o pasquim, analisando-se a "conservação" e a "redefinição" de sua primitiva forma tal qual como a história nô-la fornece; em segundo lugar, a análise do próprio produto redefinido - o pasquim da Ilha - como expressão folclórica. (id., p. 12)

Aqui, também, portanto, uma preocupação com mudança e difusão cultural, e com os reflexos ideológicos desses processos, ainda no mesmo local de eleição: a ilha de São Sebastião (ou Ilhabela). O estudo, entretanto, não cumpre tudo que é anunciado em suas intenções: após uma revisão histórica da origem dos pasquins (na antiga Roma) e de sua difusão fora do espaço italiano, é apresentado algum elemento sobre sua aclimatação no Brasil, com documentos que lhe garantem a presença desde o século XVII. A segunda parte do ensaio, mais propriamente dedicada à "conservação e reinterpretação" (id., p. 21) dos pasquins no litoral norte paulista, propicia uma discussão teórica sobre o conceito de "sobrevivência", criticado pela autora, que rastreia seu percurso na história da antropologia, de Tylor a Boas, Ruth Benedict e Herskovits. Gioconda, assim como Antonio Candido que nesse período está às voltas com a pesquisa que resultará em Os parceiros do rio Bonito, prefere o conceito de "reinterpretação", caro também, como veremos, a Roger Bastide, e dialeticamente articulado ao de "persistência". Essa parte do 
Revista de Antropologia, São Paulo, USP, 2007, v. 50 No 1.

artigo, porém, não toca no material registrado na ilha, que, também, só aparece como referência distante nas duas partes sucessivas, intituladas, mesmo assim, "O pasquim da ilha e o problema da comunicação" e "Significado e função dos pasquins”, respectivamente. Aqui, porém, a autora conclui que

[...] na medida em que o pasquim corresponde a forças sociais operantes na comunidade, inovaçōes e tradições, empréstimos de fora, etc., deixam a sua marca nos versos. Num certo sentido, o pasquim também não é mero registro. Baseando-se na experiência do grupo, deve corresponder a mudanças sociais, porquanto essas mudanças implicam redefinição da concepção de vida. O pasquineiro, quer expresse o que está subjacente, quer adiantando-se sobre a comunidade, projeta-se, dessa forma, sobre os seus ouvintes ou leitores. (id., p. 38)

Em outras palavras, é ainda o tema da mudança social, aqui, a orientar o trabalho e as consideraçôes de Gioconda Mussolini, que conclui o ensaio apresentando os textos de 13 pasquins, com numerosas notas de rodapé que esclarecem dúvidas lexicais e referências históricas, muitas das quais relativas à história local e, ao mesmo tempo, à recém-concluída Segunda Guerra Mundial. Todos, menos um, foram colhidos oralmente; e pelo menos um, "O pasquim da escola", parece improvisado, concluindo-se com duas estrofes em que a própria pesquisadora entra em cena:

Da pôca coisa qu'eu sei,

Disto mesmo o povo quê.

Senhora dona Gioconda,

E dona Maria José,

Táqui o pasquim que me pediu,

Guarda ele o que pudé. 


\author{
Meu nome é Sebastiāo. \\ Tudo o que me pede eu fais \\ Senhora dona Gioconda, \\ No dia que ela saiu, \\ Deixô sodade pra mim, \\ Pra professora inda mais.
}

Um aspecto relevante desse trabalho reside no fato de que nele é também possível flagrar o começo dos interesses da autora pelos movimentos migratórios entre o arquipélago de Ilhabela e a cidade de Santos, que, como vimos, ocupariam por completo suas preocupaçôes nos anos 1960:

Outra influência que deve ser considerada com reservas é a exercida por Santos na cultura e vida locais. Embora a comunicação com aquele porto seja constante, isso não significa que se possa falar, sem mais nem menos, em "influência da cidade grande": há verdadeiros pontos de concentração em Santos onde, ao que me informaram, "só se encontra caiçara", isto é, gente da Ilha. (id., p. 31)

Contudo, parece-me que nessa monografia, na qual ela trabalhou de 1947 a 1950, Gioconda Mussolini apenas esboça um embrião da virada metodológica que se acentuaria com mais força em 1954. Mesmo assim, o texto permite, indiretamente, mapear os locais pelos quais ela se deslocou na pesquisa de campo: Cambaquara (sul da ilha), Perequê (costa oeste), Jabaquara (norte), Bonete (sudeste), além da cidade de São Sebastião, no continente.

A produção bibliográfica sucessiva de Gioconda Mussolini é constituída pelo livro Buzios Island; a Caiçara Community in Southern Brazil (Monographs of the American Ethnological Society, Xx, New York), resultante de uma pesquisa de campo nessa ilha realizada também em 
Revista de Antropologia, São Paulo, USP, 2007, v. 50 No 1.

1947. Esse momento da trajetória da professora Gioconda constitui, ainda, um problema a ser resolvido, pois, como foi dito anteriormente, desconhecemos o verdadeiro papel desempenhado por ela tanto ao longo da pesquisa etnográfica quanto, sobretudo, na redação do texto final. O livro, com efeito, configura-se como um "estudo de comunidade" tradicional, no mesmo molde do anteriormente publicado por Willems sobre a vila de Cunha, e que havia merecido severos reparos da própria Gioconda que, em resenha publicada na Revista do Museu Paulista em 1949 (portanto, três anos antes da publicação de Buzios), considerava:

[...] nem sempre o critério acima [de consideração contrastiva das classes sociais em Cunha] é empregado [...]. Ademais se imporia, quanto a esse aspecto da estrutura social, maior articulação com o conjunto [...] de que só incidentalmente se fala numa ou noutra passagem. [...] Falta uma espécie de balanço que forneça a resultante do impacto dessas duas ordens de fatores [estabilidade e instabilidade social, ou tradição e mudança] em confronto. Este fato é responsável pela impressão de que as duas listas apresentadas são de caráter muito geral para fornecer a pintura da situação específica de Cunha [...]. O emprego concomitante geralmente feito dos termos individualização e desorganização social acaba por fundi-los de tal forma na mente do leitor que obscurece a visão dos fatos específicos [...]. A obra sobre Cunha dá a impressão de uma fuga deliberada da teoria explícita. [...] falta, a nosso ver, uma certa interação entre as proposições gerais que lhe serviram de base e os fatos particulares que ilustra, numa redefinição daquelas proposições, que impedisse a impressão de reficação de conceitos. (id., pp. 478-80)

Não são ressalvas de pouca importância, como se vê. E, naturalmente, não é possível saber se o próprio Willems teve acesso a essa resenha, já que ele, nesse mesmo ano de 1949, deixa São Paulo e a Cátedra de An- 
tropologia da USP (onde, a rigor, era o "chefe" de Gioconda) e se transfere definitivamente para os Estados Unidos. Parece sem dúvida exagerado que essa transferência repentina tenha sido ocasionada pela deterioração das relações com Gioconda (da qual a resenha seria apenas um elemento), até porque, justamente em 1952, o livro sobre Búzios é publicado por Willems, mas em co-autoria com Gioconda Mussolini. Willems, no prefácio a essa edição, já mencionado no começo deste trabalho, elogia a sua antiga colega, o que se repete, aliás, no depoimento concedido a Mariza Corrêa. Mas a questão da autoria de Buzios Island permanece.

O livro é composto de 16 capítulos, que incluem o tratamento de temas como "O assentamento físico", "O modelo de ocupação", "Anotações antropométricas", "Atividades econômicas", "Fontes de renda", "O regime de trabalho", "O sobrenatural", entre outros. Características que poderíamos reportar a uma contribuição mais efetiva de Gioconda, à luz do que vem sendo considerado até aqui, são dificilmente registráveis. A consideração do processo histórico que levou à conformação comunitária da ilha (tema caro, como vimos e veremos, à nossa autora) só merece um curto capítulo, de menos de dez páginas, dedicadas sobretudo a uma comparação entre dados de 1947 e dados contidos num breve estudo realizado por Euclides da Cunha em 1902 e publicado em 1944. O trabalho da pesca também ganha pequeno destaque, até porque tal atividade econômica, à época, não pareceu revestir relevância na economia dos moradores da ilha, aqui descritos como dedicados sobretudo à pequena agricultura de subsistência. As observações etnográficas relativas à magia e às formas tradicionais de cura das doenças (tema da recente dissertação de Gioconda) são também escassas, e o texto de Gioconda Mussolini, "Os meios de defesa contra a moléstia e a morte em duas tribos brasileiras: Kaingang de Duque de Caxias e Bororó Oriental", que já havia sido publicado na própria Revista do Arquivo Municipal (1946, com reedição em Mussolini, 1980, pp. 21-191), não é 
mencionado na bibliografia. Finalmente, a fundamentação teórica não tem maior densidade e os procedimentos metodológicos que conformam a escrita do livro não parecem adequados a refletir as agudas exigências que ela acabara de apontar na resenha à monografia precedentemente publicada por Willems sobre Cunha. Aparece, sim, uma e outra referência aos deslocamentos populacionais dos moradores da ilha (para ilhas vizinhas e para a terra firme, sobretudo para as cidades de Santos e São Sebastião), mas o tema é inserido numa perspectiva mais demográfica que sociocultural, e as observações que poderiam ser atreladas a uma consideração sobre tradição e persistência de traços culturais e ideológicos (que Gioconda elegeu como centro de atenção de seus estudos desde os primeiros artigos sobre a pesca à tainha) tampouco são incisivas. Tudo, enfim, leva a crer que a "colaboração" de Gioconda Mussolini na empreitada, embora declarada desde a capa, tenha mesmo se limitado à participação na pesquisa de campo, numa forma quantitativa e qualitativamente tão relevante que levou Willems a reconhecê-la nessa espécie de "co-autoria" relativa. Buzios Island, portanto, não seria um livro plenamente atribuível a ela, nem no conteúdo nem, muito menos, em suas conclusões, embora ele resulte de uma etnografia de que ela deve ter sido protagonista ou mesmo, em alguns passos, líder de equipe. É nessa direção que vai o depoimento de Antonio Augusto Arantes: ${ }^{10}$

Aquele trabalho que ela fez com o Willems é um trabalho muito de começo de vida. De começo de carreira. Uma coisa muito dentro da perspectiva da Escola de Sociologia e Política, onde ela foi formada. E todos os estudos dela posteriores são muito mais... esquematizam as relações de trabalho, a esfera do trabalho, a esfera da vida doméstica, a esfera das relações de parentesco, das redes. Você percebe que ela vai desconstruindo exatamente essa visão integrada, totalizante, das comunidades fechadas. E em sala de aula ela trabalhava com autores que depois a Eunice [Durham] 
Andrea Ciacchi. Gioconda Mussolini: uma travessia bibliográfica

passou a trabalhar mais sistematicamente. São os autores críticos do conceito de aculturação. (1989)

O texto apresentado por Gioconda no Congresso de Americanistas, em 1954, e que é o de maior densidade teórica entre todos os que deixou publicados, confirmará essa impressão de uma distância considerável entre Gioconda Mussolini e Emilio Willems, sobretudo nesse campo, tão polêmico e contrastado, dos estudos de comunidade, em volta do qual, aliás, se marcam e se defrontam as posições relativas dos campos da sociologia e da antropologia em São Paulo.

Em 1953, o novo professor catedrático de Antropologia da FFCLUSP, Egon Schaden, antigo colega de Gioconda desde os anos de estudo, embora se licenciasse em Filosofia, funda a Revista de Antropologia, na qual Gioconda publicará, logo no segundo número do primeiro volume, o artigo "Aspectos da cultura e da vida social no litoral brasileiro". A primeira versão desse artigo foi publicada, em alemão, no StadenJahrbuch, revista do Instituto Martius-Staden de São Paulo. ${ }^{11} \mathrm{O}$ instituto foi criado em 1916 como uma associação de professores alemães do maior colégio alemão que existia na época na capital paulista, a Deutsche Schule, e tinha o objetivo de oferecer cursos de alemão aos brasileiros e de português aos alemães que chegavam ao Brasil, além de organizar festas, palestras, peças de teatro, concertos e projetos de trabalho. Em 1935, essa associação passou a se chamar Associação Hans Staden, constituindo-se em 1938 como Sociedade Hans Staden. Nessa ocasião, o instituto tomou posse do Arquivo da História da Colônia Alemã em São Paulo, fundado pelo Colégio Alemão em 1925. Na época da Segunda Guerra Mundial, a entidade teve de interromper suas atividades, mas voltou a funcionar a partir de 1947 sob o nome de Instituto Hans Staden. O primeiro Staden-Jahrbuch foi publicado em 1953 pelo antigo Instituto Hans Staden. Seu editor foi o próprio Egon Schaden. 
Revista de Antropologia, São Paulo, USP, 2007, v. 50 No 1.

Sua introdução para o primeiro volume do anuário começa com as seguintes palavras:

O Staden-Jahrbuch tem o objetivo de oferecer uma visão do Brasil e se dirige ao leitor de língua alemã. $\mathrm{O}$ anuário só leva em consideração temas que tratem do Brasil, do país e de seu povo, uma limitação que logo traz à tona uma unidade entre o variado material apresentado. ${ }^{12}$

No mesmo número em que Gioconda publica o artigo sobre o litoral brasileiro, também aparecem artigos de Schaden (sobre os "teutobrasileiros"), de Anatol Rosenfeld (sobre a "situação dos negros no Brasil"), de Lourival Gomes Machado (sobre o barroco em Minas Gerais e o Aleijadinho) e de José Aderaldo Castelo (sobre tendências do moderno romance brasileiro). Outros autores que assinam freqüentemente artigos nessa revista, nos anos 1950 e 1960, são Antonio Candido, Roger Bastide, Maria Isaura Pereira de Queiroz, Florestan Fernandes, Harald Schultz, Fernando Henrique Cardoso, Marialice Foracchi, Thekla Hartmann, João Baptista Borges Pereira e Renate Viertler, o que atesta a proximidade entre o grupo do Instituto e o curso de Ciências Sociais da FFCL. O texto é uma espécie de introdução ao conjunto de elementos sociais e culturais que caracterizam a vida de várias comunidades pesqueiras ao longo da costa do Brasil. Nenhum aspecto se sobressai sobre outros, e o artigo, aliás, pretende afirmar algumas idéias que serão destinadas a ter grande repercussão nos estudos sucessivos no Brasil. O primeiro é que o "imenso litoral brasileiro" compartilha "elementos culturais e sociais comuns a todo ele" (Mussolini, 1980, p. 220), o que é argumentado pela autora com base em determinações históricas e geográficas. Aquelas mais do que estas, aliás, pois Gioconda trata de recusar qualquer abordagem determinista para mergulhar numa rápida mas consistente explanação historiográfica que remete às características da ocu- 
pação litorânea desde os primórdios do período colonial. Se o foco do estudo é nacional, claro está que é em relação à situação de São Paulo que a autora é mais generosa em termos históricos e etnográficos. Nessa região localiza-se o fenômeno que, inclusive em outros trabalhos, Gioconda reputa ser uma das características da configuração pesqueira do litoral:

Decaindo, os núcleos de povoamento que eles [os portos de Ubatuba, São Sebastiāo e Iguape] centralizavam voltaram a fechar-se sobre si mesmos, entregando-se a uma economia quase sem trocas, com o decorrente estreitamento do seu horizonte econômico e cultural. (id., p. 223)

A partir daí, o artigo aprofunda-se na apresentação da documentação historiográfica, para, em seguida, apresentar uma classificação tipológica das técnicas de captura e dos instrumentos utilizados, já que

uma grande variedade local é condicionada não apenas pelo predomínio de certas influências culturais específicas e pela disponibilidade de capital, como também pelas conveniências funcionais que tornam certos aparelhamentos mais adequados a determinados tipos de costa, além da matéria-prima disponível para sua confecção ou do peixe mais comum ou preferido na área. (id., p. 230)

Assim, os aspectos materiais do trabalho da pesca são relacionados aos econômicos, que lhes determinam formas e condições de mudança, como, mais uma vez, a autora mostra utilizando o caso de Santos, pois

um segmento qualquer, mesmo entregue a uma economia fechada, se entrosa num conjunto maior. Dessa forma, não raro o equilíbrio da vida social e a cultura desses pequenos aglomerados se modificam por fatores 
Revista de Antropologia, São Paulo, USP, 2007, v. 50 No 1.

que exercem sua ação a distância, atraindo para a órbita de influência dos centros de que se irradiam os moradores das pequenas unidades marginais. (id., pp. 238-9)

O estudo mostra, paralelamente, uma maior segurança de Gioconda Mussolini, sobretudo na possibilidade de entrelaçar dados históricos, econômicos, culturais e etnográficos pertencentes ao litoral brasileiro como um todo, inclusive em função da mais ampla literatura disponível nesse momento dos anos 1950. A bibliografia arrolada pela autora já compreende agora a tese de cátedra de Ary França, professor de Geografia Humana da FFCL-USP (1951), o conhecido artigo de Carlos Borges Schmidt sobre a pesca no litoral paulista (1948), ele mesmo fortemente influenciado pelos estudos pioneiros de Gioconda sobre a pesca da tainha, além de textos mais antigos e provavelmente lidos mais recentemente, como as crônicas de Hans Staden sobre os Tupinambá, Nordeste, de Gilberto Freyre (1937), A pesca na Amazônia, de José Veríssimo (1895) e o Ensaio sobre as construçôes navais indígenas do Brasil, de Antônio Alves Câmara (1888). Por outro lado, o lastro teórico da autora é também alimentado por Josué de Castro (A geografia da fome, 1946), Roberto Simonsen (História econômica do Brasil, 1937) e, sobretudo, Caio Prado Júnior (Formação do Brasil Contemporâneo, 1945).

Em 1954, ano do IV Centenário da capital paulista, acontece em São Paulo o XXXX Congresso Internacional de Americanistas. Como é natural, a presença de cientistas sociais da FFCL da USP é maciça. Ao lado de colegas como Antonio Candido, Antonio Robbo Müller, Egon Schaden, Florestan Fernandes, Maria Isaura Pereira de Queiroz, Oracy Nogueira, Otávio da Costa Eduardo, Paula Beiguelman, Ruy Coelho, entre outros, e de antropólogos de outras instituições e de geraçôes distintas, como Candido Mariano Rondon, Heloisa Alberto Torres, Eduardo Galvão, Darcy Ribeiro, Ernest Baldus, Roberto Cardoso 
de Oliveira, Harald Schultz, José Loureiro Fernandes, Luiz de Castro Faria, René Ribeiro e Thales de Azevedo, além de estudiosos e professores residentes no exterior mas com significativa passagem pelo Brasil nos anos de formação e de atuação profissional de nossa autora, como Alfred Metraux, Charles Wagley e Donald Pierson, ${ }^{13}$ Gioconda Mussolini apresenta a comunicação "Persistência e mudança em sociedades de 'folk' no Brasil", publicada nos Anais do Congresso no ano sucessivo.

Trata-se de seu trabalho com maior fôlego teórico e que, embora não tematize diretamente populaçóes pesqueiras, mais ilumina seus artigos dedicados à temática principal da trajetória intelectual de Gioconda. Colocado, cronologicamente, no meio dessa trajetória, esse estudo serve para subsidiar a fundamentação teórica da autora, nem sempre explícita nos textos até aqui já examinados, e para apontar os rumos que ela trilharia se a ele não seguisse, na realidade, um longo silêncio bibliográfico, culminado com a não conclusão da tese de doutorado e, finalmente, com sua morte em 1969. Ao mesmo tempo, o artigo também constitui uma prestação de contas de Gioconda Mussolini com seu contexto epistemológico e disciplinar, mostrando como, cerca de 15 anos após a conclusão do curso na FFCL, ela filtrava e selecionava influências diretas e indiretas, abordagens e paradigmas metodológicos, inclusive em diálogo com o que a Cadeira de Sociologia I, em particular, exatamente no período de transição entre Bastide e Florestan Fernandes, oferecia a ela como "alternativa" teórica viável e concreta.

O filtro aciona-se principalmente para a lição que, com base na Escola de Chicago, e por meio de alguns dos seus antigos professores, como Donald Pierson e Emilio Willems, sobretudo, havia colocado claramente a produção de Gioconda Mussolini no cenário brasileiro dos "estudos de comunidade". Manifestando claramente a sua opção por um tratamento histórico dos dados empíricos registrados nas etnografias, ela situa-se ao lado de seu também velho mestre, o geógrafo francês Pierre 
Revista de Antropologia, São Paulo, USP, 2007, v. 50 No 1.

Monbeig, reivindicando que só esse tratamento, capaz, portanto, de distinguir entre as "zonas velhas" e as "zonas pioneiras", permite apreender a dinâmica social e cultural que envolve "conservantismo" e "mudança". Em outras palavras, o texto de Gioconda, declarando desde os primeiros momentos a opção por uma metodologia atenta à dialética entre persistência e mudança, constrói um roteiro teórico que inclui Monbeig, para logo em seguida descartar, em Chicago, Robert Redfield, para, portanto, na mesma escola norte-americana, indicar a sua preferência pelos estudos de George Foster. Nisso, elegantemente mas com firmeza, critica tanto Emilio Willems como Donald Pierson, seguidores, no Brasil, da lição de Redfield:

\footnotetext{
Quase que invariavelmente [...] os estudos de comunidade realizados no Brasil revelam [...] interesse definido da parte dos seus autores por áreas nas quais se espera verificar a qualidade da "organização cultural" e estabilidade social, selecionando-se, por essa razão, pontos que, além de situados nas "zonas velhas" de povoamento, sejam o suficiente isolados para que se anteveja a possibilidade de concretização daquela expectativa [...]. Implícita ou explicitamente, alguns desses estudos, pelo menos, ${ }^{14}$ têm procurado testar no Brasil as conclusões de Redfield e, dessa forma, têm prescindido grandemente de uma investigação histórica rigorosa das comunidades estudadas. (Mussolini, 1955, p. 338)
}

A crítica de Gioconda, portanto, não se limita à opção metodológica mas chega a atingir os critérios de seleção das comunidades estudadas por alguns de seus colegas e ex-professores. Mas era essa a atitude mais freqüente no campo da antropologia paulista e, até então, as únicas críticas a ela haviam surgido no campo da sociologia e, especialmente, dos integrantes mais destacados da Cadeira de Sociologia I: seu catedrático, Roger Bastide, e seu primeiro assistente, Florestan Fernandes. ${ }^{15} \mathrm{~A}$ posi- 
ção de Gioconda Mussolini, portanto, volta-se contra a atitude "culturalista" que Willems, principalmente, havia legado ao campo paulista da antropologia, sobretudo nos anos 1940, atitude à qual não é possível vincular o nome de nossa jovem professora, que, com repetidas referências a artigos de seu antigo chefe na Cadeira de Sociologia, Roger Bastide, parece alinhar-se ao lado dos ex-colegas, reivindicando uma atenção mais efetiva para as questôes "sociais", históricas e econômicas.

E não é outra a sua posição nos artigos que consideramos até agora, de forma que a sua vinculação com a "vertente culturalista" só pode ser atribuída (e mesmo assim com muito cuidado) à sua atuação docente, realizada, de 1941 a 1949, sob a direção do próprio Willems e, desse ano até 1969, sob a chefia de Egon Schaden, ele próprio um entusiasta seguidor da postura de Willems, de quem fora primeiro assistente na Cadeira de Antropologia até 1949. Mas, como vimos e como ainda verificaremos com seu derradeiro artigo sobre pesca, o distanciamento de Gioconda Mussolini da "modalidade clássica de realização" dos estudos de comunidade (Franco, 1963) é nítido. O que, aliás, parece resolver a questão relativa à autoria da monografia sobre a ilha de Búzios, em que o nome de Gioconda Mussolini, na capa do livro, aparece, acredito, à sua revelia teórico-metodológica. As diferenças entre esse estudo e o anteriormente publicado pelo professor alemão, dedicado à vila de $\mathrm{Cu}-$ nha e criticado por Gioconda, são impalpáveis.

Assim, num só gesto, Gioconda marca a sua posição teórica, colocase com clareza em um dos dois campos em disputa e, dessa forma, sela uma espécie de "traição" aos colegas da Cadeira de Antropologia da FFCL, até mesmo a seu chefe e futuro orientador, Egon Schaden. É nessa chave, portanto, que não só deve ser lido o significado e o alcance de seus estudos sobre pesca, mas, também e sobretudo, deve ser avaliada a posição institucional que ela ocupa. $\mathrm{O}$ desconforto que deriva desse posicionamento - pois o Congresso de Americanistas acaba e a rotina 
Revista de Antropologia, São Paulo, USP, 2007, v. 50 No 1.

na rua Maria Antônia continuaria -, durante longos 16 anos, não deve ter deixado de atingir a esfera pessoal, na qual se inserem tanto a amizade e a cumplicidade com Florestan Fernandes, profundas e duradouras, quanto o "fracasso" de sua tese de doutoramento, que, como testemunha Antonio Arantes, ${ }^{16}$ afirmaria essa orientação metodológica apesar de ser orientada, acadêmica e oficialmente, por Egon Schaden:

\footnotetext{
Schaden era o bastião da aculturação. Daquela antropologia culturalista americana, na qual a Gioconda foi formada, mas da qual ela estava se afastando. [...] Porque ela era contemporânea do Schaden. Eram pessoas da mesma idade, então, os dois tinham uma tensão entre eles a respeito da cadeira de antropologia, era claramente uma tensão. [...] Eles não se entendiam.
}

E foi, justamente como se sabe (cf. Ciacchi, 2007), a não conclusão da tese o elemento decisivo, no plano friamente institucional (para não dizer burocrático), para o estacionamento da carreira docente de Gioconda, que não pôde suceder Schaden na direção da Cadeira de Antropologia quando da aposentadoria deste, em 1967, por não possuir o título de doutora.

Se não fosse, talvez, demasiado distante dos objetivos deste artigo, caberia ler nessa perspectiva o significado de uma outra tese de doutorado, desenvolvida nesse mesmo período e nesse mesmo lugar institucional: a dedicada por Antonio Candido aos Parceiros do rio Bonito. O mesmo diálogo entre sociologia, antropologia, história e geografia informa os artigos de Gioconda e a tese de Antonio Candido, talvez os mais fiéis guardiões da lição trazida para a FFCL em seus primeiros anos, sobretudo, pela missão francesa. O "desconforto" institucional de Antonio Candido (à época assistente de Fernando de Azevedo na Cadeira de Sociologia II) resolveu-se na saída dele da FFCL e do campo 
das ciências sociais, como se sabe, e em sua ida para a Faculdade de Filosofia de Assis e para o campo dos estudos literários. Já o de Gioconda alimentaria um conjunto mais amplo de frustrações. Claro está, entretanto, que existem imensas diferenças entre as posiçōes institucionais de Antonio Candido, no final dos anos 1950, e de Gioconda Mussolini, em meados da década sucessiva. ${ }^{17}$

Em outro plano, é essa também a posição expressa por José de Souza Martins, ex-aluno de Gioconda, o qual considera que

os pequenos e esparsos estudos de Gioconda Mussolini são fundamentais para entender as diretrizes teóricas de estudos sobre o caipira, como os de Antonio Candido, seu contemporâneo. Obviamente, há grandes diferenças entre os trabalhos de ambos, mas há também uma certa referência comum. Gioconda enfatizou mais as limitaçôes epistemológicas das concepçôes de comunidade e da tendência a estudar comunidades tradicionais, enquanto Candido destacou a historicidade que se escondia na teoria da transição. Há neles, portanto, uma renovação de perspectivas, sobretudo teóricas, além de uma nova compreensão do que é o Brasil. (Martins, 1998, p. 126)

Na realidade, como vimos, esse "resgate" da historicidade está presente, também e antes, na orientação de Gioconda, tendo sido mais clamorosamente declarado na resenha crítica à monografia de Willems sobre Cunha. O que, aliás, o próprio Souza Martins reconhece mais adiante, quando, ao comentar justamente a influência de Monbeig sobre Antonio Candido, lembra que

o amplo espaço a ser ocupado e as formas inventivas de criação do novo, das novas comunidades e dos novos agrupamentos sociais na fronteira econômica e demográfica do país [...] [foram] um tema que também preocupava Gioconda Mussolini. (id., p. 127) 
É exatamente esse o ponto principal abordado no trabalho apresentado no Congresso de Americanistas, que, aos poucos, se encaminha para a vinculação entre essa posição e os estudos sobre pesca, quando Gioconda, após ilustrar alguns exemplos etnográficos, sobretudo relativos à ilha de São Sebastião, mostra que "a influência externa [leva] à mudança não por aquisições culturais ou organizatórias de fora [como talvez afirmasse a tradição ligada a Willems e ao próprio Schaden], mas pela criação de problemas para os quais a comunidade local tenha que achar soluçôes" (Mussolini, 1950, pp. 350-1). Portanto, "um estudo de comunidade deve ser sempre complementado pelo dos demais centros com que mantenha relações (principalmente quando ocorre essa flutuação de população)” (id., p. 351).

A relevância desse artigo pode ser avaliada por um episódio póstumo de sua fortuna crítica. Uma parte do texto de Gioconda Mussolini será inserida por Florestan Fernandes na coletânea por ele organizada, em 1972, Comunidade e sociedade no Brasil. Leituras básicas de introdução ao estudo macro-sociológico do Brasil, na seção II, "A pequena comunidade", ao lado de excertos de Os parceiros do rio Bonito, de "Sociologia e folclore: a dança de S. Gonçalo num povoado bahiano" (Maria Isaura Pereira de Queiroz, 1958), e de Messianismo e conflito social: a Guerra Sertaneja do Contestado (Maurício Vinhas de Queiroz, 1966). Na apresentação dessa seção, Florestan afirma que

a contribuição de G. Mussolini põe em questão problemas de natureza teórica, numa linha interpretativa que transcende, aqui e ali, a "sociedade de folk" propriamente dita. Contudo, essa constitui uma das unidades didáticas mais frutíferas deste livro, pois o estudante precisa adestrar-se na arte do raciocínio teórico. (Fernandes, 1975, p. 48) ${ }^{18}$ 
As conclusões mais radicais dessa renovada e polêmica, até certo ponto, posição de Gioconda Mussolini, atravessam seu derradeiro artigo, "Os japoneses e a pesca comercial no litoral norte de São Paulo", publicado na Revista do Museu Paulista em 1963, ${ }^{19}$ portanto após quase dez anos de silêncio da autora. Antes de examinar brevemente seu conteúdo, cabe assinalar que no curriculum vitae que Gioconda produziu em 1965, na seção "Trabalhos publicados, em andamento, etc." (p. 4), a ele seguem dois itens:

- Está realizando uma pesquisa sobre "A contribuição dos japoneses à pesca paulista”. Esse trabalho, que visa a integrar o interesse a propósito da organização da pesca em nosso litoral (principalmente em seus aspectos sociais) e o interesse sobre a aculturação dos japoneses no Brasil, está sendo feito à base de pesquisas na Ilha de São Sebastião, na cidade de Santos e na Ilha Grande (Estado do Rio).

- Está redigindo a tese de doutoramento sobre "Um estudo de comunidade", que tem como centro de análise a Ilha de São Sebastião (litoral norte do Estado de São Paulo). (grifo meu)

É completamente viável, porém, a hipótese de que, na realidade, a tese de doutoramento buscasse integrar aqueles dois interesses; ou seja, que a tese não se configuraria bem como um "estudo de comunidade", mas como um trabalho de fôlego teórico e metodológico mais amplo, que tanto confirmaria as opções epistemológicas presentes nos trabalhos anteriores como a que se manifesta nesse último artigo de 1963. Disso deriva a também verossímil hipótese de que foi, entre outros elementos e questões, a dificuldade de tal integração de perspectivas e mesmo de alcance temático a inviabilizar a redação da tese, até mesmo diante da provável discordância de seu orientador, Egon Schaden, quanto à fundamentação e oportunidade de tal empreitada. 
Revista de Antropologia, São Paulo, USP, 2007, v. 50 No 1.

$\mathrm{O}$ artigo, que revela a maturidade da pesquisadora e da estudiosa, retoma, de fato, aspectos temáticos presentes em trabalhos anteriores, mas os assenta num quadro mais amplo. A imagem inicial é um retrato eficaz dos objetivos da autora nessa fase:

Numa análise sincrônica da pesca, poderíamos aproveitar a sugestão oferecida pelos próprios barcos em seu deslocamento e, estrategicamente, nos situar ora num ora noutro extremo das suas rotas. Abrangeríamos, assim, toda a trama que envolve os grandes mercados de pesca e as pequenas comunidades pesqueiras numa relação complementar necessária, ainda que mutável. (Mussolini, 1980, p. 243, grifos meus)

Objetivos explicitados mais adiante:

Nossa apresentação focaliza três itens aparentemente desconexos mas que, na realidade, correspondem a facetas de um mesmo processo histórico. São eles: $1^{\circ}$ ) a introdução, na Ilha de São Sebastião, de uma rede de pesca, o cerco flutuante, que a tradição local conservaria com o nome de "cerco de japonês"; 20) a instalação, na área, das "salgas", pequenas indústrias destinadas à produção de um elemento da dieta japonesa, o "iriko" (peixe seco); $3^{\circ}$ ) a participação dos japoneses na pesca santista, na qualidade de armadores. (id., pp. 247-8)

O tratamento analítico desses três elementos, ao qual é fundamental uma novidade metodológica como os registros de numerosas entrevistas com armadores e empresários (e não somente, portanto, com "pequenos" pescadores, como acontecia nos trabalhos anteriores), cujas trajetórias profissionais são traçadas e restituídas pela autora, permite a Gioconda Mussolini 
não só acompanhar uma fase do desenvolvimento da própria pesca em Santos, como também apreender, ainda que de maneira geral, por ora, a especificidade dessa forma de exploração econômica. Esses problemas, que pretendemos cercar com outros dados, nos interessam não apenas porque permitem precisar o tipo de influência que, a partir de Santos, vai incidir nas pequenas comunidades litorâneas (preservando-nos de, a priori, sobrecarregar o contraste entre uma organização "capitalista" e outra "não-capitalista”), como também as perspectivas socioeconômicas que se abriram e se abrem ao migrante da costa paulista naquele centro urbano. (id., p. 256, primeiro grifo da autora, o segundo meu)

Está posta aí a integração entre as duas esferas que, quase com certe$\mathrm{za}$, seriam mais amplamente abordadas na tese. Como pensar, de fato, que esta só se recortaria de uma delas, contradizendo, aliás, todo o esforço dessa breve mas intensa trajetória bibliográfica da autora? E também está posto aí mais um movimento de aproximação de Gioconda ao programa intelectual (e institucional) que vinha, cada vez mais, caracterizando o trabalho de Florestan Fernandes, a essa altura já instalado como chefe da Cadeira de Sociologia I da FFCL. Parece, de fato, mais que provável que, no lugar de uma caracterização culturalista da dialética entre persistência e mudança, nas formas que, por exemplo, se consolidariam na própria Cadeira de Antropologia, prestes a ser regida pelo professor João Baptista Borges Pereira, o enfoque de Gioconda se encaminharia com mais firmeza para as questôes sociais envolvidas no cenário que ela ia traçando nesse movimento dinâmico e recíproco entre "pequena pesca artesanal" e pesca comercial, entre pequenas comunidades litorâneas e grandes centros urbanos e industriais, acompanhando os sentidos e os rumos das migraçôes internas. Assim, uma perspectiva de classe acabaria aparecendo e prevalecendo. 
Dessa forma, a análise do conjunto dessa produção bibliográfica, seja a destinada a abordar o trabalho da pesca no litoral paulista, seja aquela mais voltada para a discussão teórica e metodológica, assim como o reconhecimento da "direção" dessa produção, no sentido de um progressivo afinamento epistemológico e mesmo temático, de uma análise "microssociológica" para uma "macrossociológica", permitem alguns avanços na tarefa do esclarecimento da posição de Gioconda Mussolini nos campos paulista e brasileiro da antropologia entre os anos 1940 e 1960. Ela parece constituir um corpo, ao mesmo tempo, estranho - se considerarmos as escolhas temáticas, teóricas, metodológicas e institucionais da Cadeira de Antropologia da FFCL - e heterodoxo - se incluirmos no cenário o caminho empreendido pela Cadeira de Sociologia I, com Bastide antes e Florestan Fernandes depois.

E, paradoxalmente, um corpo dificilmente resgatável, após a morte. Não interessou muito aos antropólogos, aos quais, afinal, ela "pertencia”, pelos desvios e afastamentos que ela promoveu com relação a eles, nem aos sociólogos, a cujos quadros, de fato, ela não pertencia, embora lhes abraçasse e compartilhasse elementos da agenda temática e das posições metodológicas.

Nesse sentido, não resisto à tentação de parafrasear para ela a expressão famosa que Ruy Coelho dedicou a Florestan Fernandes: Gioconda Mussolini era uma ilha de sociologia cercada por antropologia por todos os lados. Depois de cerca de duas décadas passadas na Cadeira de Antropologia, Gioconda encontra-se numa "situação epistemológica" em que, mais apropriadamente, os seus interlocutores estão alojados na Cadeira de Sociologia I, a mesma, e de novo paradoxalmente, em que ela havia iniciado a sua carreira docente na FFCL, de 1938 até 1944. $\mathrm{Ou}$, parafraseando mais um, terá sido Gioconda uma "desterrada em sua própria Cadeira”? 
É nesse quadro que se compreende mais uma questão que revela os móveis do esquecimento póstumo de Gioconda. A década que se abre após a morte dela (e que na USP é marcada por uma desterritorialização simbólica como a transferência definitiva da Faculdade da rua Maria Antônia para a Cidade Universitária) corresponde ao surgimento de novos programas de pós-graduação em Ciências Sociais e à consolidação de alguns mais antigos, o que acarretará numerosas e variadas conseqüências. Entre elas, nas palavras de Afrânio Garcia Jr. e Mario Grynszpan, o fato de que

\footnotetext{
a pesquisa de campo ganha um prestígio que só conhecera no passado em círculos restritos. ${ }^{20}[\ldots]$ há uma valorização da entrevista direta com os agentes sociais para se captar as representações imediatas como um instrumento indispensável de compreensão da realidade social. [...] Não é estranho que a monografia de Antonio Candido sobre Os parceiros do rio Bonito (1964) e os trabalhos de Maria Isaura Pereira de Queiroz, como Bairros rurais paulistas (1973) e O campesinato brasileiro (1973), fossem recorrentemente citados como referências passadas que compartilhavam a mesma valorização do rigor empírico que os estudos dos anos de 1970. Observese, porém, que os estudos de comunidade realizados por antropólogos e sociólogos norte-americanos desde os anos de 1950, muitos deles inspirados diretamente pela Escola de Chicago, não tiveram a mesma receptividade. (Garcia Jr. \& Grynszpan, 2002, pp. 311-48)
}

Vale dizer que os "deslocamentos" de Gioconda passaram despercebidos, e é muito razoável que isso tenha ocorrido pelo fato de eles terem se concretizado em artigos isolados e escassos (sobretudo na comunicação de 1954 e no estudo de 1962) e não terem desembocado na peça esperada: a tese de doutoramento. A falta desta, portanto, repercutirá também post-mortem, embaralhando posiçóes e pertencimentos. Nem 
Revista de Antropologia, São Paulo, USP, 2007, v. 50 No 1.

tão antropóloga nem tão socióloga, nem mais "culturalista" nem suficientemente purificada das máculas dos velhos estudos de comunidade, Gioconda torna-se uma espécie de Tiago Aipobureu uspiana: "solitária entre os seus e estranha aos estranhos" (Baldus, 1937, p. 184).

Invisível e invisa ao mesmo tempo, Gioconda parece ter feito por merecer esse esquecimento. $\mathrm{O}$ âmbito empírico em que ela foi buscar sua realização como pesquisadora, como se não bastassem os outros empecilhos, eram as distantes ilhas e praias do litoral norte de São Paulo, à etnografia das quais ela ligou seu nome. Não conseguiu finalizar o estudo que acrescentaria àquele conjunto a cidade de Santos e a apreensão da questão migratória. Difícil, portanto, aliás impossível, que a ela se reconhecesse a prática daquele "ponto de partida metodológico implícito" na tradição do pensamento social da escola sociológica paulista: que "a análise a partir da periferia permite indagar sobre os princípios que articulam o sistema” (Bastos, 2002, p. 201). O território praiano, líquido e incerto, parecia periférico demais e nunca esteve nem estaria no centro do campo brasileiro das ciências sociais nem no topo de sua hierarquia temática. De fato, aliás, algumas relevantes trajetórias acadêmicas surgidas na década de 1970 e no começo da sucessiva freqüentaram, de início, esse território, para, mais cedo ou mais tarde, voltaremse para âmbitos mais "fortes" ou em vias de fortalecimento. Penso em nomes como os de Alcida Rita Ramos, Luiz Fernando Dias Duarte, Roberto Kant de Lima e Marco Antônio Mello, no Rio de Janeiro, Mariza Peirano, em Brasília, e Fernando Mourão, na própria USP.

Por outro lado, e não menos importante, haja vista o significado inicial da busca do lugar de Gioconda nesses campos, aí incluindo o que por ora pode ser definido como o "subcampo" dos estudos de socioantropologia marítima e da pesca, não será inócuo localizar, em muitos trabalhos e trajetórias sucessivos à morte de Gioconda, um rastro importante da perspectiva a que estava chegando a nossa autora. Penso, 
para um programa mínimo e inicial de pesquisa, na dissertação de mestrado em sociologia defendida por Antonio Carlos Diegues na USP, em 1973, com a orientação de Fernando Mourão, aluno, por sua vez, de Gioconda Mussolini. O trabalho, Pesca e marginalização no litoral paulista, é certamente devedor dessa renovada perspectiva epistemológica inaugurada por Gioconda. Perspectiva que encontrará talvez a sua realização mais completa na tese de doutorado em sociologia (1980), ainda orientada por Mourão, do mesmo Diegues. Intitulada Pescadores, camponeses e trabalhadores do mar, e publicada numa coleção muito difundida em âmbito acadêmico, ela marca a retomada de uma tradição interrompida pela morte da professora paulistana e que daria frutos que ainda estão em plena fase de desenvolvimento nos dias de hoje.

\section{Notas}

1 Este ano corresponde a seu ingresso como assistente na Cadeira de Sociologia I da FFCL. Em 1944 Gioconda transfere-se para a Cadeira de Antropologia, fundada em 1941.

2 Entre as poucas exceções, as mais relevantes são a entrevista concedida por José de Souza Martins a Luiz Carlos Jackson (Martins, 1998) e o artigo de Fernanda Arêas Peixoto e Júlio Assis Simões (2003).

3 Este trabalho, desdobramento da comunicação oral apresentada na X Reunião de Antropólogos do Norte e Nordeste (ABANNE, Aracaju, outubro de 2007), apresenta apenas uma parte dos resultados parciais de um eixo de minha pesquisa de pós-doutorado, desenvolvida no Departamento de Antropologia da Unicamp. A pesquisa geral é dedicada ao delineamento dos elementos constituintes do campo da antropologia da pesca ou marítima, no Brasil, desde o começo do século XX. Em outras duas ocasióes (Ciacchi, 2007a e 2007b), apresentei, respectivamente, os materiais relativos à reconstrução biográfica e à discussão da atuação docente de Gioconda Mussolini na USP. Permance ainda inédito um balanço das posiçōes teó- 
Revista de Antropologia, São Paulo, USP, 2007, v. 50 № 1.

ricas e metodológicas da autora que aparecem nas numerosas resenhas bibliográficas por ela publicadas em revistas acadêmicas da época.

Deixo aqui os meus agradecimentos a colegas e alunos de Gioconda que, através de entrevistas e depoimentos, me proporcionaram uma contribuição generosa e incalculável para estes trabalhos: Antonio Candido, João Baptista Borges Pereira, Renate Viertler, Amadeu Lanna, Antonio Augusto Arantes, Ruth Leite Cardoso, Fernando Henrique Cardoso, José de Souza Martins, Antonio Carlos Diegues e Heloísa Fernandes. Agradeço, também, a interlocução constante, apaixonada e preciosa com Heloísa Pontes e Mariza Corrêa, da Unicamp, com Laura Moutinho, Dimitri Silva e Claudinei Spirandelli, da USP, e com Wilton Silva, da Unesp.

Finalmente, não posso deixar de registrar a satisfação de ver a "volta" de Gioconda Mussolini às páginas da Revista de Antropologia, na qual, desde a sua fundação, em 1953, foi assídua e incansável animadora.

4 A trajetória de Heloisa Alberto Torres na antropologia brasileira começa antes da de Gioconda: ela ingressou no Museu Nacional, como auxiliar de Roquette-Pinto em 1918, aos 23 anos. Em seguida, foi eleita chefe interina da Seção de Antropologia e Etnografia e chefe efetiva desde 1931. De 1935 a 1937 foi vice-diretora do Museu, e diretora de 1938 a 1955. Entretanto, ela não se dedicou sistematicamente ao ensino superior, até pela oposição, à época, de Arthur Ramos na Faculdade Nacional de Filosofia. Uma assistente de Ramos, Marina Vasconcelos, vinha lecionando antropologia desde 1941 nessa instituição. Conferir Corrêa (1997).

5 Glaucia Villas Boas (2000, p. 182) informa, entretanto, que a pesquisa de campo foi realizada apenas nos meses de janeiro, março, junho e julho de 1945. A mesma autora também lista os colaboradores de Willems, definindo-os, porém, "alunos" o que não se aplica, evidentemente, a Gioconda e Florestan, pelo menos.

6 Pelo testemunho de João Baptista Borges Pereira, uma moça "perguntou por que ele havia retirado o nome da cidade, Cunha, do título da segunda edição do livro. Então ele contou que, ao ser lançado o livro, os cunhenses sentiram-se profanados em sua intimidade e vieram para São Paulo, sitiaram a faculdade, querendo brigar com ele. Aí Oracy Nogueira, que é de Cunha, resolveu intermediar. Chegou lá e explicou aos exaltados conterrâneos que aquele era um trabalho científico sério. Em resposta, o prefeito disse a Oracy que ele era cunhense mas não teve nenhum gesto para evitar que Willems deixasse Cunha de cuecas na rua. Aí, para evitar 
problemas, ele lançou a segunda edição com o nome de Uma vila brasileira" (Marras, 2003, p. 334).

7 Oscar Rezende de Lima se tornará docente da Escola Paulista de Medicina, no campo da psicanálise; Íris Koehler militará na paleontologia, realizando pesquisas sobre sambaquis no litoral brasileiro.

8 Utilizo a paginação da reedição desses e de outros textos de Gioconda Mussolini na coletânea organizada por Edgar Carone: Ensaios de antropologia indígena e caiçara (1980).

9 Os pasquins são, no litoral norte de São Paulo, versos cantados de tema político ou de atualidade e intuito polêmico ou satírico.

$10 \quad$ Maio de 2007.

11 No curriculum vitae de 1965, Gioconda refere o título alemão do artigo, publicado originalmente no Staden-Jahrbuch, do Instituto Hans Staden de São Paulo, em "1954", o que deve indicar um atraso na seriação da Revista de Antropologia. O título em alemão do artigo é "Die Lebensweise der brasilianischen Küstenbevölkerung".

12 http://www.martiusstaden.org.br. Acesso em 14/3/2008.

13 A relação completa está nas páginas iniciais dos Anais do Congresso. Emilio Willems, já estabelecido em Vanderbilt há dois anos, está ausente.

14 Em nota de rodapé, a autora cita a monografia de Willems sobre Cunha e a de Pierson sobre Cruz das Almas - os seus verdadeiros alvos.

15 Conferir "debate" travado no "Symposium sobre classes sociais", publicado no volume x da revista Sociologia, em 1948, em que sobretudo a contraposição explícita se dá entre Emilio Willems, de um lado, e Florestan Fernandes, de outro. Só mais tarde será travado debate semelhante, com contraposição entre Oracy Nogueira (a favor dos estudos de comunidade) e Otávio Ianni (contra). Conferir Corrêa (1995) e Peixoto e Simões (2003).

16 Em entrevista concedida ao autor, em maio de 2007.

17 Não tenho espaço para desenvolver aqui uma questão que, no mínimo, remete ao fato de que, enquanto Antonio Candido era, já naquela época, um autor bastante produtivo, com trabalhos expressivos no âmbito dos estudos literários, Gioconda era uma autora "ocasional", num contexto acadêmico e institucional em que ainda era possível a um professor passar dez anos sem publicar. Além disso, razōes distintas estão na raiz da transferência de Candido para uma universidade de me- 
Revista de Antropologia, São Paulo, USP, 2007, v. 50 No 1.

nor prestígio e na permanência de Gioconda na Antropologia da USP. Conferir Pontes (1998) e Ramassote (2006).

18 O volume é inserido na mesma coleção da Companhia Editora Nacional, na qual em 1969 havia sido publicado Evolução, raça e cultura, organizado por Gioconda Mussolini.

19 O trabalho foi originalmente apresentado na VI Reunião Brasileira de Antropologia, realizada em São Paulo em 1963. Mariza Corrêa (2003, p. 29) reproduz uma fotografia de uma refeição em que Gioconda Mussolini, sorridente, aparece em companhia de Roberto Da Matta, Julio César Melatti, Castro Faria, Oracy Nogueira e Maria Laís Mousinho Guidi, entre outros.

20 Entre eles, justamente, a ELSP e a Cadeira de Antropologia da FFCL-USP.

\section{Bibliografia}

ARANTES, Antonio Augusto

1989 "20 anos da morte de Gioconda Mussolini”, Boletim da ABA, n. 7, out., p. 8.

BASTOS, Elide Rugai

2002 "Pensamento social da escola sociológica paulista", in MICELI, Sergio (org.), O que ler na ciência social brasileira, 1970-2002, São Paulo, Sumaré, pp. 183-232.

BALDUS, Herbert

1937 "O professor Tiago Marques e o caçador Aipobureu: a reação de um indivíduo bororo à influência da nossa civilização", in Ensaios de etnologia brasileira, São Paulo, Companhia Editora Nacional, pp. 163-86.

BERNARDES, Lysia Maria Cavalcanti \& BERNARDES, Nilo

1950 "A pesca no litoral do Rio de Janeiro", Revista Brasileira de Geografia, vol. 12(1): $17-53$.

CANDIDO, Antonio

1947 "Opinião e classes sociais em Tietê", Sociologia, vol. Ix(2): 97-112. 
Andrea Ciacchi. Gioconda Mussolini: uma travessia bibliográfica

CARONE, Edgard

1980 "Nota explicativa", in MUSSOLINI, Gioconda, Ensaios de antropologia indigena e caiçara, Rio de Janeiro, Paz e Terra.

CIACCHI, Andrea

2007a "A mulher que puxou a rede. Gioconda Mussolini e os estudos sobre pesca no Brasil", VII Reunião de Antropologia do Mercosul, CD-ROM.

2007b "As testemunhas do silêncio. Gioconda Mussolini entre lembranças e esquecimento", trabalho apresentado na $31^{\text {a }}$ Reunião da ANPOCS, de 22 a 26 de outubro, Caxambu, MG. Disponível em: http://201.48.149.89/anpocs/arquivos/11 $10 \quad 2007 \quad 12 \quad 11$ 28.pdf. Acesso em 1/12/2007.

CORRÊA, Mariza

1987 História da antropologia no Brasil (1930-1960). Testemunhos: Emilio Willems; Donald Pierson, Campinas, Vértice/Unicamp.

1995 "A antropologia no Brasil (1960-1980)", in MICELI, Sergio (org.), História das ciências sociais no Brasil, São Paulo, Sumaré/Fapesp, vol. 2, pp. 25-106.

1997 "Dona Heloisa e a pesquisa de campo", Revista de Antropologia, vol. 40(1): 11-54.

2003 As reuniōes brasileiras de antropologia: cinqüenta anos (1953-2003), Brasília, ABA.

DIEGUES, Antonio Carlos

1973 Pesca e marginalização no litoral paulista, São Paulo, Nupaub/Cemar/USP.

1983 Pescadores, camponeses e trabalhadores do mar, São Paulo, Ática.

FERNANDES, Florestan

1948 "A análise sociológica das classes sociais", Sociologia, vol. X, pp. 91-113.

1975 Comunidade e sociedade no Brasil. Leituras básicas de introdução ao estudo macrosociológico do Brasil, 2.ed., São Paulo, Companhia Editora Nacional.

FRANCO, Maria Sylvia de Carvalho

1963 "O estudo sociológico de comunidades", Revista de Antropologia, vol. 11(1-2): 29-39. 
Revista de Antropologia, São Paulo, USP, 2007, v. 50 No 1.

GARCIA JR., Afrânio \& GRYNSZPAN, Mario

2002 "Veredas da questão agrária e enigmas do grande sertão", in MICELI, Sérgio (org.), O que ler na ciência social brasileira - 1970-2002, São Paulo, Sumaré, pp. 311-348.

JACKSON, Luiz Carlos

2004 "A sociologia paulista nas revistas especializadas (1940-1965)", Tempo Social, vol.16(1): 263-83.

2007 "Gerações pioneiras na sociologia paulista (1934-1969)", Tempo Social, vol. 19(1): 115-30.

MARRAS, Stélio

2003 "Pessoa e instituição - entrevista com João Baptista Borges Pereira", Revista de Antropologia, vol. 46(2): 319-45.

MARTINS, José de Souza

1998 "Os parceiros do Rio Bonito e a sociologia na Universidade de São Paulo", in FERNANDES, Florestan, Sociologia e consciência nacional no Brasil, São Paulo, Edusp, pp. 109-44.

MUSSOLINI, Gioconda

1949 "Resenha de Cunha", Revista do Museu Paulista, 8, vol. III, pp. 477-80.

1950 "Os pasquins do litoral norte de São Paulo e suas peculiaridades na Ilha de São Sebastião", separata da Revista do Arquivo Municipal, 134, São Paulo, Departamento de Cultura.

1955 "Persistência e mudança em sociedades de folk no Brasil", Anais do XXXI Congresso Internacional de Americanistas, vol. I, São Paulo, Anhembi, pp. 333-53.

1980 Ensaios de antropologia indígena e caiçara, Rio de Janeiro, Paz e Terra.

s/d Documentos de Gioconda Mussolini, Arquivos da Seção de Protocolo, Administração da FFLCH-USP.

PEIXOTO, Fernanda

2001 "Franceses e norte-americanos nas ciências sociais brasileiras (1930-1960)", in MICELI, Sergio (org.), História das ciências sociais no Brasil, São Paulo, Vértice, vol. 1, pp. 477-532. 
Andrea Ciacchi. Gioconda Mussolini: uma travessia bibliográfica

PEIXOTO, Fernanda Arêas \& SIMÕES, Júlio Assis

2003 "A Revista de Antropologia e as ciências sociais em São Paulo: notas sobre uma cena e alguns debates", Revista de Antropologia, vol. 46(2): 383-409.

PONTES, Heloísa

1998 Destinos mistos; os críticos do Grupo Clima em São Paulo - 1940-1968, São Paulo, Companhia das Letras.

RAMASSOTE, Rodrigo

2006 A formaçāo dos desconfiados: Antonio Candido e a crítica literária acadêmica (1961-1978), dissertação de mestrado em Antropologia, Campinas, Unicamp.

VILLAS BOAS, Glaucia K.

2000 "De Berlim a Brusque de São Paulo a Nashville: a sociologia de Emilio Willems entre fronteiras", Tempo Social, vol. 12, pp. 171-88.

WILLEMS, Emilio

1948 "Velhos e novos rumos no estudo das classes sociais", Sociologia, vol. X, pp. 76-90.

WILLEMS, Emilio \& MUSSOLINI, Gioconda

2003 A Ilha de Búzios, São Paulo, Hucitec/Nupaub. 
Revista de Antropologia, São Paulo, USP, 2007, v. 50 № 1.

ABSTRACT: In this paper, I present a few more results from a research work aimed at reconstructing the intellectual trajectory of Professor Gioconda Mussolini, a pioneer in the teaching of anthropology at USP's School of Philosophy, from 1944 to 1969 . Here, I review her most representative production: six articles and a co-authored book, texts on several aspects of the cultural and social life of fishing populations on the coast of São Paulo State, produced between 1944 and 1961, as a result of numerous, intensive field research studies. The object of this analysis is to show how the set of methodological attitudes revealed in the formulation of the texts leads to a critical overcoming of "community studies," in whose context Gioconda had graduated, both as a student at USP and the Free School on Sociology and Politics, and as a colleague and coworker of representatives of this school (Donald Pierson, Emilio Willems, and Egon Schaden, among others). In this aspect, she shares, to a certain extent, her colleagues' view, such as those of Antonio Candido and Florestan Fernandes. Lastly, I point out the first elements which enable connecting her production to the successive paths in the field of ethno-anthropology of fishing in Brazil.

KEY-WORDS: Gioconda Mussolini, Anthropology and Sociology in Brazil, anthropology of fishing.

Recebido em novembro de 2007, aceito em dezembro de 2007. 